conflict. The more globalization affects the prevailing local norms, customs and practices, the greater the likelihood of social conflicts, which may even lead to a change in political regimes.

\title{
References:
}

1. Antonini L. Globalizzazione e nuove sfide del costituzionalismo. Diritto pubblico. 2019. T. 25, №. 2. P. 319-340.

2. Coppelli Ortiz G. La globalización económica del siglo XXI. Entre la mundialización y la desglobalización. Estudios internacionales (Santiago). 2018. T. 50, №. 191. P. 57-80.

3. Rayón Ballesteros M. C. La globalización: su impacto en el estado-nación y en el derecho. Revista Jurídica Derecho. 2018. T. 7, №. 8. P. 19-37.

4. Saskia S. The State and Globalization 1. The Third Way Transformation of Social Democracy. Routledge, 2017. P. 59-72.

\section{DOI https://doi.org/10.30525/978-9934-26-116-9-44}

\section{ДОГОВІРНІ ЗАСАДИ ТРАНСФЕРУ ТЕХНОЛОГІЙ У СФЕРІ ІНТЕЛЕКТУАЛЬНОЇ ВЛАСНОСТІ}

\section{Величко А. А.}

аспірант кафедри інтелектуальної власності та інформачійного права Інституту права Київського національного університету імені Тараса Шевченка м. Київ, Україна

Трансфер технології - передача технології, що оформляється шляхом укладення між фізичними та/або юридичними особами двостороннього або багатостороннього договору, яким установлюються, змінюються або припиняються майнові права та обов'язки щодо технології та/або її складових (підпункт 13 пункту 1 ст 1 ЗУ «Про державне регулювання діяльності у сфері трансферу технологій»).

Сторони трансферу технологій взаємодіють між собою шляхом створення технологій та/або ї складових; обміну досвідом та інформацією про наукові досягнення; проведення консультацій з науковотехнічної питань щодо складових технології та методів їх застосування; укладення інших договорів у сфері трансферу технологій відповідно до законодавства. 
На міжнародній торговій арені трансфер технології за його ознаками, прийнято поділяти на:

1. Внутрішній, при якому проводиться передача промислової власності або специфічної технології по підрозділах організації.

2. Квазівнутрішній, при якому здійснюється рух промислової власності або специфічної технології всередині союзів та об'єднань юридичних осіб.

3. Зовнішній, при якому здійснюється процес поширення промислової власності та технології за участі незалежних розробників та споживачів технологій.

4. Міжнародний трансфер технологій та промислової власності.

Також поділяють за формою технології:

1. Матеріальні (повна передача підприємства, спеціалізоване обладнання та інструмент).

2. Нематеріальні (патенти та ліцензії, ноу-хау, шоу-хау, знання та досвід працівників, документація).

3. Технологічні послуги (науково-технічні, фінансово-інжинірингові та консультативні).

Та за характером договору.

Комерційного характеру: Ліцензійна діяльність (патентування та ліцензування, торгівля ліцензіями та їх обмін, уступка патентів, франчайзинг (комерційна концесія)). Фінансовий та інші вид інжинірингу (проектно- технологічний, документарний, управлінський).Торгівля. Інноваційна діяльність у сфері трансферу технологій.

Некомерційного характеру: Обмін науково-технічною інформацією (публікації, спеціалізовані виставки та ярмарки, науково-технічні центри, сезонна міграція спеціалістів, заохочення до технологічної освіти). Науково-дослідні та дослідно-конструкторські роботи та науковотехнічне співробітництво (система формування спільних програм розвитку у контексті розробки науково-технічних програм, співробітництво науково- технічних центрів, стимулювання розвитку науки та техніки, регулювання діяльності міжнародних організацій щодо передачі технологій).

Не зважаючи на ознаки, форму та характер договору, однією із основних вимог до договору є грошова оцінка об'єктів створених в результаті інтелектуальної діяльності. Під час проведення оцінки майнових прав інтелектуальної власності встановлюються обставини та визначаються обмеження, пов'язані з особливостями таких об'єктів $\mathrm{i}$ сфери їх застосовування.

Процес проведення оцінки для складання договору у сфері трансферу технологій має складатися 3:

1. Ідентифікації об’єкта оцінки; 
2. Правової експертизи ОІВ (перевірка наявності охоронних документів (свідоцтв, патентів), їх дійсності); Під час обстеження об’єкта права інтелектуальної власності, яке проводиться 3 метою його ідентифікації, з'ясовується наявність матеріального носія об'єкта та документів, що засвідчують майнові права інтелектуальної власності і факт видачі дозволу на використання об'єкта права інтелектуальної власності;

3. Економічної експертизи ОIВ (перевірка відображення в бухобліку, дослідження економічного ефекту);

4. Збір та аналіз вихідної інформації.

5. Вибір необхідних методичних підходів, методів та оціночних процедур, що найбільш повно відповідають меті оцінки та обраній базі, визначеним у договорі на проведення оцінки, та їх застосування.

6. Узгодження результатів оцінки, отриманих із застосуванням різних методичних підходів.

7. Складання звіту про оцінку майна та висновку про вартість об’єкта оцінки на дату оцінки.

8. Доопрацювання (актуалізація) звіту та висновку про вартість об'єкта оцінки на нову дату (у разі потреби).

На законодавчому рівні України до основних нормативно-правових актів, що регулюють процес інвентаризації, оцінки та трансферу об'єктів інтелектуальної власності належать:

- Закон України "Про оцінку майна, майнових прав та професійну оціночну діяльність в Україні";

- Закон України "Про наукову і науково-технічну діяльність";

- Закон України "Про наукову і науково-технічну експертизу";

- Закон України "Про інноваційну діяльність";

- Закон України "Про державне регулювання діяльності у сфері трансферу технологій";

- Положення бухгалтерського обліку № 8 "Нематеріальні активи";

- Постанова Кабінету міністрів України "Про затвердження сплати зборів за дії, пов'язані з охороною прав на об'єкти інтелектуальної власності";

- Національний стандарт № 4 "Оцінка майнових прав інтелектуальної власності";

- Наказ Фонду державного майна України "Про затвердження Методики оцінки майнових прав інтелектуальної власності".

Причиною наявності лише основних засад та відсутністю чітко визначених міжнародних вимог до договорів у сфері трансфер технологій інтелектуальної власності є унікальна специфіка даного виду договору, що унеможливлює конкретизацію алгоритму складання та вміст таких договорів. 
Не зважаючи на складність реалізації трансферу технології та його відносну новизну у правовому полі, держави що активно користуються трансфером технологій та постійно вдосконалюють процес державного регулювання даної сфери кратно збільшують свій інтелектуальний капітал. Провідне місце на світовому ринку трансфер технологій займають - Японія, Німеччина, США, Велика Британія, Франція, Італія, КНР. За підрахунками на дані країни припадає близько $90 \%$ ліцензійних надходжень від імпорту ліцензій. Разом 3 тим імпорт ліцензій також відіграє важливу роль в інноваційному розвитку країн.

\section{Література:}

1. Святун О. «Правове регулювання передачі технологій в Свропейському Союзі» / Олена Святун, Олексій Святун // Вісник Київського національного університету імені Тараса Шевченка. Міжнародні відносини. - 2009. - № 37. - С. 63-66.

2. Плотников В. Ю. «Патентование изобретений и продажа лицензий на внешнем рынке» / В. Ю. Плотников, Е. Н. Плотникова. - М. : Бизнес-школа Интел-синтез, 1999. - 208 с.

3. Евдокимова В. Н. «Вопросы правового регулирования передачи технологии в РФ» / ИС Промышленная собственность. - 2004. № 9-10. - С. 154-158

4. Денисюк О. П. Проблеми та перспективи розвитку охорони інтелектуальної власності в Україні / О. П. Денисюк // Адвокат. 2009. - № 7. - C. 38-41

5. Федоренко В.Л. Проблеми теорії та практики судової експертизи 3 питань інтелектуальної власності («Крайнєвські читання»): Матер. II Міжнар. науково-практ. конф. (20 грудня 2018 р., м. Київ)

6. Панферова Л.Л. «Методи вартісної оцінки трансферу технологій» Збірник наукових праць IV Всеукраїнської науково-практичної конференції- семінару з проблем економіки інтелектуальної власності ст 165-179.

7. Омельченко А.В. «Особливості трансферу технологій як предмета правового регулювання» \Збірник наукових праць IV Всеукраїнської науково-практичної конференції- семінару 3 проблем економіки інтелектуальної власності ст. 161-165.

8. Закон Бей-Доула від 1980 p., https://web.archive.org/ web/20050308125745/http://www.access.gpo.gov/nara/cfr/waisidx_02/37cfr 401_02.html

9. Закон США від 1986 р., «Про федеральний трансфер технологій» http://thomas.loc.gov/cgi-bin/bdquery/z?d099:H.R.3773: 